\title{
Correlation of Nogo A release with glia scar formation in spinal cord injury
}

\author{
Correlação da liberação do Nogo A com a formação da cicatriz da glia na lesão medular \\ Correlación de la liberación de Nogo A con la formación de cicatrices gliales en la lesión de la \\ médula espinal
}

Received: 05/02/2021 | Reviewed: 05/10/2021 | Accept: 05/12/2021 | Published: 05/29/2021

\author{
Juliana Casanovas de Carvalho \\ ORCID: https://orcid.org/0000-0002-3152-3184 \\ Universidade Estadual do Maranhão, Brazil \\ E-mail: juju.casanovas@hotmail.com \\ César Augusto Abreu- Pereira \\ ORCID: https://orcid.org/0000-0003-0665-9060 \\ Universidade Estadual Paulista, Brazil \\ E-mail: cesar.abreu@unesp.br \\ Lucas Cauê da Silva Assunção \\ ORCID: https://orcid.org/0000-0002-2512-9762 \\ Universidade Estadual do Maranhão, Brazil \\ E-mail: lucascaue04@gmail.com \\ Rosana Costa Casanovas \\ ORCID: https://orcid.org/0000-0002-6871-3491 \\ Universidade Federal do Maranhão, Brazil \\ E-mail: rosana.c.casanovas@hotmail.com \\ Ana Lucia Abreu-Silva \\ ORCID: https://orcid.org/0000-0003-2167-3725 \\ Universidade Estadual do Maranhão, Brazil \\ E-mail: abreusilva.ana@gmail.com \\ Matheus Levi Tajra Feitosa \\ ORCID: https://orcid.org/0000-0002-9247-8532 \\ Universidade Estadual do Maranhão, Brazil \\ E-mail: matheusfeitosa@professor.uema.br
}

\begin{abstract}
Several axonal growth inhibitors have already been identified following spinal cord injury, the most known being myelin-derived proteins, such as Nogo-A. The present study aimed to correlate the formation of glial scar with the beginning of growth inhibitor, Nogo-A, release in rats previously submitted to compressive spinal cord injury. For this, 12 male and female Wistar rats $(250 \pm 50 \mathrm{~g})$ were divided into 3 groups of 4 animals each, according to the animals' euthanasia time after spinal cord injury (G3 - three days; G5 - five days; G7 - seven days). Spinal cord injuries were induced by means of dorsal laminectomy of the T10 vertebra and epidural compression. Histopathological evaluation and immunoreactivity of the Nogo-A axonal growth inhibitor were performed. It was observed that there was the release of the axonal inhibitor Nogo-A after $24 \mathrm{~h}$ after the occurrence of spinal cord injury, and that the glial scar must be maintained, in this time interval, in order to guarantee the rebalancing of the posttrauma environment. Thus, it is suggested that the glial scar should be maintained in the acute phase of the lesion, guaranteeing its numerous benefits for the rebalancing of the post-injured environment and, after 24 hours, when the release of the studied axonal growth inhibitor begins, it should be removed.
\end{abstract}

Keyword: Healing; Neuroglia; Animal models.

\section{Resumo}

Diversos inibidores de crescimento axonal já foram identificados acompanhando a lesão medular, sendo as mais conhecidas as proteínas derivadas de mielina, como o Nogo-A. O presente trabalho teve como objetivo correlacionar a formação da cicatriz glial com o início da liberação do inibidor de crescimento axonal Nogo-A em ratos previamente submetidos à lesão medular compressiva. Para isso, 12 ratos Wistar, machos e fêmeas $(250 \pm 50 \mathrm{~g})$, foram divididos em 3 grupos de 4 animais cada, de acordo com o tempo de eutanásia dos animais após a lesão medular (G3 - três dias; G5 - cinco dias; G7 - sete dias). Foi realizada a indução das lesões medulares por meio de laminectomia dorsal da vértebra T10 e compressão epidural. A avaliação histopatológica e da imunorreatividade do inibidor de crescimento axonal Nogo-A foram realizadas. Foi observado que houve a liberação do inibidor axonal Nogo-A a partir de $24 \mathrm{~h}$ após a ocorrência de lesão medular, e que cicatriz da glia deve ser mantida, nesse intervalo de tempo, para que garanta o reequilíbrio do meio pós-trauma. Dessa forma, sugere-se que a cicatriz glial deve ser mantida na fase aguda da 
lesão, garantindo seus inúmeros benefícios ao reequilíbrio do ambiente pós-lesionado e, após $24 \mathrm{~h}$, quando se inicia a liberação do inibidor de crescimento axonal estudado, esta deve ser removida.

Palavras-chave: Cicatrização; Neuroglia; Modelos animais.

\section{Resumen}

Ya se han identificado varios inhibidores del crecimiento axonal después de una lesión de la médula espinal, siendo los más conocidos proteínas derivadas de la mielina, como Nogo-A. El presente estudio tuvo como objetivo correlacionar la formación de cicatrices gliales con el comienzo de la liberación del inhibidor del crecimiento. Axonal Nogo-A en ratas previamente sometidas a lesión medular por compresión. Para ello, se dividieron 12 ratas Wistar macho y hembra $(250 \pm 50 \mathrm{~g})$ en 3 grupos de 4 animales cada uno, según el tiempo de eutanasia de los animales tras la lesión medular (G3 - tres días; G5 - cinco días; G7 - siete días). Las lesiones medulares se indujeron mediante laminectomía dorsal de la vértebra T10 y compresión epidural. Se realizó la evaluación histopatológica y la inmunorreactividad del inhibidor del crecimiento axonal Nogo-A. Se observó que hubo liberación del inhibidor axonal Nogo-A a las 24 h de ocurrida la lesión medular, y que la cicatriz glial debe mantenerse, en este intervalo de tiempo, para garantizar el reequilibrio del postraumatismo. ambiente. Así, se sugiere que la cicatriz glial se mantenga en la fase aguda de la lesión, garantizando sus numerosos beneficios para el reequilibrio del ambiente post-lesionado y, a las 24 horas, cuando comience la liberación del inhibidor del crecimiento axonal estudiado, debería ser eliminado.

Palabras-clave: Curación; Neuroglia; Modelos animales.

\section{Introduction}

Spinal cord injuries occur through traumatic or non-traumatic pathways, with progression almost always catastrophic, especially when there are locomotor deficits such as paraplegia or quadriplegia (Lee et al., 2014, Alibardi, 2020). Spinal trauma can have an extrinsic origin, including fractures and dislocations secondary to bone diseases, such as congenital vertebral anomalies, neoplasms of vertebrae and nutritional alterations, and traumatic disc herniation, and extrinsic ones through fractures, dislocations and vertebral subluxations, resulting from traumatic events (Glass; Kent, 2007; Zhang et al., 2020).

According to the World Health Organization - WHO (2013) between 250,000 and 500,000 people suffer spinal cord injuries each year, where $90 \%$ of cases are of traumatic origin. Brazil follows the same perspective, with about 250,000 spinal cord injuries per year (Meyer et al., 2013).

The spinal cord injury is divided into primary and secondary pathological processes, where the formation of the glial scar occurs in the secondary phase of the spinal cord injury, consisting of reactive astrocytes, macrophages and extracellular matrix molecules, especially chondroitinproteoglycan sulfate (SCPG), forming a barrier to axonal regeneration. The inhibitory effects of scar tissue are considered the main obstacle to nerve tissue regeneration (Huang et al, 2014; Yang et al., 2020).

Axonal growth inhibitors have been identified following spinal cord injury, with myelin-derived proteins being more well-known, such as Nogo-A, myelin-associatedglycoprotein (MAG) and oligodendrocytemyelinglycoprotein (OMG). These inhibitors are associated with the formation of the glial scar, following the spinal cord injury process (Huang et al, 2012; Adams and Gallo, 2018).

The elimination of the glial scar is one of the main objectives in the treatment of spinal cord injury, however, for many years it was believed that the glial scar was a solely limiting factor, since it induced the production of axonal growth inhibitors important in the regeneration process. However, Rolls et al. (2009), demonstrate several benefits for spinal cord regeneration through the formation of the glial scar, with few deleterious effects, mainly related to the production of inhibitory hormones.

The present study aims to contribute to the understanding of the pathophysiological processes of spinal cord injury, through the correlation between the formation of the glial scar and the beginning of the release of the Nogo-A axonal growth inhibitor. 


\section{Material and Methods}

\subsection{Experimental Design}

The project was submitted to and approved by the Ethics Committee on Animal Experimentation at CEUMA University (UNICEUMA) under protocol number 12/2018, Twelve male and female Wistar rats $(250 \pm 50 \mathrm{~g})$ were used, divided into 3 groups of 4 animals each, according to the animals' euthanasia time (G3 - euthanized group after three days of spinal cord injury, G5 - five days, G7 - seven days), from the Biotérium Laboratory of Surgical Skills "José Henrique Moreira Lima", from the UNICEUMA and from the Central Vivarium of the State University of Maranhão (UEMA). The experiments were conducted at UNICEUMA. The animals were kept under monitored conditions with a temperature equivalent to $26 \pm 1{ }^{\circ} \mathrm{C}$, with food and water ad libitum, in a 12-hour light / dark cycle. The experiments were carried out according to the guide for care and use of laboratory animals from the Department of Health and Human Services of the United States of America (USA), Washington, DC.

\subsection{Institution of Spinal Cord Injury}

For the institution of spinal cord injury, the animals were manually restrained and submitted to an anesthetic protocol consisting of intraperitoneal (IP) combination of ketamine hydrochloride (75mg / kg), xylazine hydrochloride (3mg / kg) and diazepam $(3 \mathrm{mg} / \mathrm{kg})$. After anesthetic induction and confirmation of the surgical anesthetic plan due to the absence of the corneal reflex and absence of deep pain (confirmed by the interdigital compression of the paws), the rats were placed in the sternal decubitus position and fixed on the operating table. The beginning of the surgery was through the dorsal laminectomy of the T10 vertebra for subsequent institution of the spinal cord injury. The spinal cord injury was performed by epidural compression with the introduction of a size $2 \mathrm{~F}$ Fogarty embolectomy catheter through the laminectomy performed on the T10 vertebra, advancing the catheter cranially to the T8-T9 vertebrae. The catheter tip balloon was inflated using $15 \mu 1$ of saline and the compression was maintained for 10 minutes.

\subsection{Postoperative care of animals}

Postoperative care of animals was performed in accordance with the United States of America (USA) Department of Health and Human Services (USA), Washington, DC Department of Care and Use of Laboratory Animals. Analgesia was provided with administration of tramadol hydrochloride at a dose of $12.5 \mathrm{mg} / \mathrm{kg}$ and dipyrone monohydrate at a dose of $600 \mathrm{mg} / \mathrm{kg}$, twice a day, for 5 consecutive days. Anti-inflammatory treatment was performed with ketoprofen at a dose of $5 \mathrm{mg} / \mathrm{kg}$, subcutaneously, once daily for 3 consecutive days. Antibacterial prophylaxis was provided with administration of enrofloxacin $2.5 \mathrm{mg} / \mathrm{kg}$ every 12 hours for 7 days. The animals were evaluated daily for behavior and psychomotor deficits with the behavioral test Basso, Beattie and Bresnahan, seizures, presence of fistula, healing process, bruises and signs of infection. It is worth mentioning that, in addition to basic care, the animals were submitted to bladder emptying by means of manual palpation, twice a day, in addition to intestinal emptying, if necessary.

\subsection{Animal Euthanasia}

To collect the necessary material and perform histological evaluations, the animals were euthanized through anesthetic deepening with ketamine (Syntec Brasil Ltda, SP, Brazil) and xylazine (Schering-Plow Coopers, SP, Brazil), intraperitoneally. The spinal cord was dissected, and the meninges and nerve roots removed. The region of the instituted spinal cord injury was cut and fixed in a $10 \%$ formaldehyde solution for 24 hours. 


\subsection{Histopathological evaluation by hematoxylin and eosin staining}

This step was aimed at evaluating the quality of conservation of the material destined for histological processing. The collected regions were cut into cubes with sides measuring approximately $0.5 \mathrm{~cm}$ and placed in $4 \%$ paraformaldehyde, remaining for 24-48 hours for complete fixation. Then, the material was dehydrated in a series of ethanols in increasing concentrations (from 70 to 100\%) and diaphanized in xylol, with later inclusion in paraffin (Paraplast ${ }^{\circledR}$ ). In paraffin blocks, cuts of five micrometers $(5 \mu \mathrm{m})$ thick were obtained using a microtome (Leika, German) and were stained with HematoxylinEosin. The slides were read by light microscopy (40x).

\subsection{Evaluation of Nogo-A axonal growth inhibitor expression}

The sections included in paraffin were fixed on silanized slides and the best slides were used for the reaction with the antibodies. Then, immunohistochemistry was performed to detect the specific antibody. Tissue sections included in paraffin were dewaxed in xylol and hydrated in decreasing concentrations of ethyl alcohol. The sections were washed with phosphatesaline buffer (PBS). Antigen recovery was performed using a microwave oven (Consul, Brazil), maximum power, in 10mM sodium citrate buffer (pH6.0) for approximately 3 minutes uncapped and then for another 3 minutes capped. Followed by washing with deionized eagle and aspiration of excess liquid from the blades. The blocking of nonspecific reactions was performed with $6 \%$ skimmed milk. The samples were incubated with the primary antibody diluted (1:200 - 1:400) in blocking serum at $0.5-5.0 \mathrm{mg} / \mathrm{ml}$, in a humid atmosphere, overnight, in a refrigerator. The slides were washed in PBS. The samples were incubated with the biotinized secondary antibody for an additional 30 minutes, in the same laboratory conditions, interspersed with washes in PBS and then incubated for an additional 30 minutes with the HRP - streptavidin complex and washed again in PBS. Then, HRP substrate (mixture) was added, allowing it to act for 10 minutes. Finally, the slides were rinsed with deionized water and developed with the ImmunocruzStaining System SC-2050 - Santa Cruz Biotechnology, against Harrys' hematoxylin staining and the immunohistochemical reaction with the antibodies was performed on 10 slides of each animal.

\section{Results}

\subsection{Histopathological evaluation by hematoxylin and eosin staining}

The slides observed under light microscopy were classified into two quality scores: satisfactory (Figure 1A) and unsatisfactory (Figure 1B). The slides with unsatisfactory scores showed signs of poor fixation of the material and errors in the microtomy technique, being redone for further evaluation and further immunohistochemistry. In addition, histopathological findings were evidenced, such as: hemorrhage (Figure 1C) glial cells and gitter cells (vacuolized spaces due to phagocytosis of the myelin sheath by microglia cells (Figure 1D). 
Figure 1: Histopathological analyzes. A- Photomicrography of a satisfactory score slide; B - Photomicrograph of an unsatisfactory score slide; C- Wistar rat spinal cord, 24h after surgery - Photomicrograph of longitudinal section of the spinal cord showing extensive areas of hemorrhage (black asterisks); D- Wistar rat spinal cord, five days after surgery - Longitudinal cut photomicrograph with the presence of gitter cells (black arrows) and glial cells (white arrow).

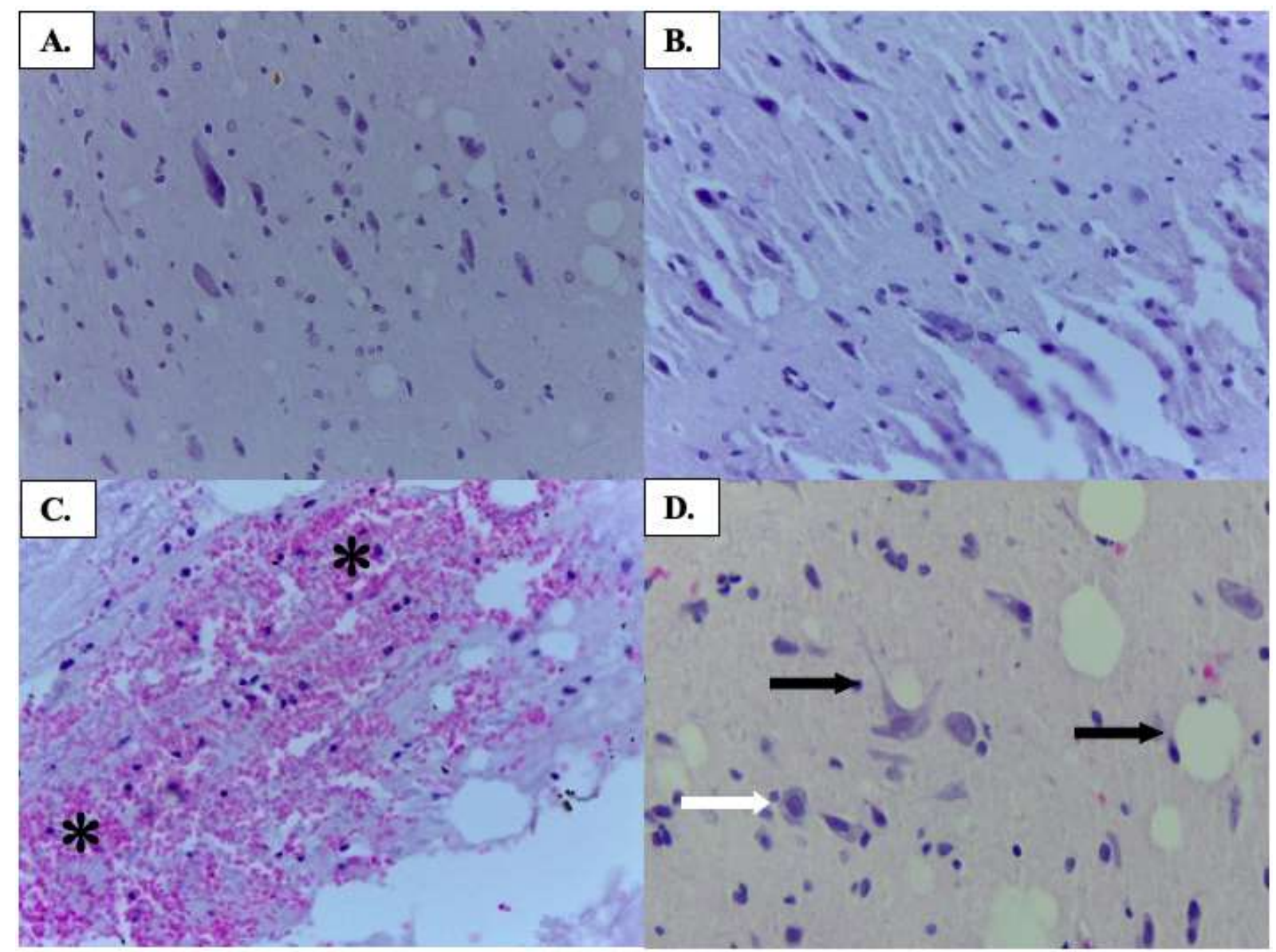

Source: Authors.

\section{2 immunoreactivity assessment of NOGO-A axonal growth inhibitor}

After performing the necessary procedures for immunohistochemistry, the silanized slides with longitudinal cuts of the spinal cord, incubated with the anti-NOGO-A antibody, were analyzed under light microscopy. The material obtained was evaluated using the sample times shown in the table below. Such results were achieved since the animals died before the times foreseen in the methodology, allowing a better analysis of the immunoreactivity period of the NOGO-A axonal growth inhibitor. The slides were read under light microscopy and the presence or absence of antibody markings was observed, evidenced in a brownish color. The photomicrographs obtained were selected and those of better quality were shown in Figure 2. 
Figure 2: Longitudinal cut photomicrograph immunoreactivity of the Nogo inhibitor A - with antibody marking in brow. AWistar rat spinal cord 24h after surgery - black arrow; B- Wistar rat spinal cord 32h after surgery black arrows; C- Wistar rat spinal cord, three days after surgery - black arrows; D- Wistar rat spinal cord seven days after surgery - with antibody mark in pale brown (black asterisks).

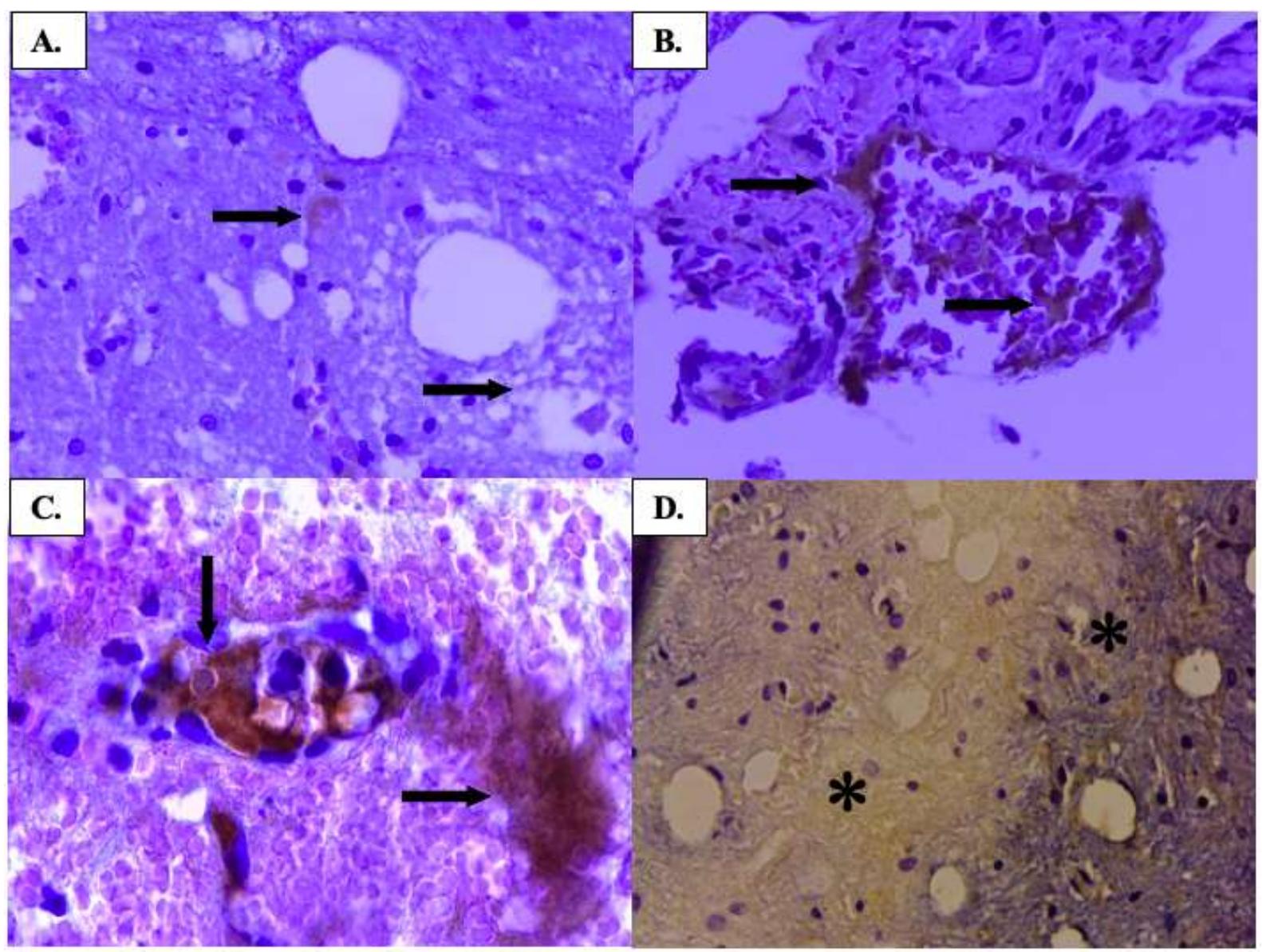

Source: Authors.

\section{Discussion}

The proposed methodology aimed to elucidate the understanding of the pathophysiological processes of spinal cord injury, through the correlation between the formation of the glial scar and the beginning of the release of the Nogo-A axonal growth inhibitor.

In a study with a methodology similar to that applied in this study, Wang and collaborators (2015) reported through their results that the beginning of the release of Nogo-A was detected after $24 \mathrm{~h}$ of the induction of spinal cord injury, corroborating with our results, where it was also observed that, after the first 24 hours after the induced injury, there was the release of the axonal growth inhibitor Nogo-A.

The repair model after an induced injury is configured by a gradual process in a dynamic way, where the determining and associated factors for a successful repair can vary according to the recovery stage, having different characteristics between the initial (acute) phase and the recovery phase (chronic) (Sun et al, 2020). In this way, the glial scar and its entire cycle play a fundamental role in the acute phase, restoring homeostasis and contributing to the spared tissue, modulating immunity (Adams and Gallo, 2018; Li, et al., 2020).

The negative aspects of the glial scar appear to be due to an excessive scar formation response, and not due to its presence. This non-standardized response can be explained through the evolution process, where the recovery from trauma in 
the CNS was not a strong driving force (Sofroniew, 2005; Yang et al., 2020). Trauma and mild injuries may have induced stronger evolutionary processes due to the need to restore homeostasis, even if it is necessary to lose a limited number of neurons, replacing the need for new growth. Therefore, it is possible that the repair mechanisms present, including the formation of glial scars, have not been modified during the evolution processes (Rolls et al., 2009; Tang, 2020).

Therefore, when analyzing the potential of the glial scar in the repair, it is noted that it is possible to obtain a maximum benefit from its presence, and specific therapies can be developed to act on the scar tissue or induce its regeneration through adjustment in the ideal time window for your application. Thus, it is essential that the literature expands to ensure greater efficacy in the treatment of spinal cord injury, since studies with more restricted post-injury time spans are necessary, making it possible to know the exact moment of the beginning of the release of Nogo-A.

\section{References}

Adams, K. L., \& Gallo, V. (2018). The diversity and disparity of the glial scar. Nature neuroscience, 21(1), 9-15. https://doi.org/10.1038/s41593-017-0033-9

Alibardi L. (2020). Nogo-A immunolabeling is present in glial cells and some neurons of the recovering lumbar spinal cord in lizards. Journal of morphology, 281(10), 1260-1270. https://doi.org/10.1002/jmor.21245

Aslam, A. F., Aslam, A. K., Vasavada, B. C., \& Khan, I. A. (2006). Cardiac effects of acute myelitis. International journal of cardiology, 111(1), 166-168. https://doi.org/10.1016/j.ijcard.2005.06.018

Carwardine, D., Prager, J., Neeves, J., Muir, E. M., Uney, J., Granger, N., \& Wong, L. F. (2017). Transplantation of canine olfactory ensheathing cells producing chondroitinase $\mathrm{ABC}$ promotes chondroitin sulphate proteoglycan digestion and axonal sprouting following spinal cord injury. PloS one, 12(12), e0188967. https://doi.org/10.1371/journal.pone.0188967

Gajic, O., \& Manno, E. M. (2007). Neurogenic pulmonary edema: another multiple-hit model of acute lung injury. Critical care medicine, 35(8), 1979-1980. https://doi.org/10.1097/01.CCM.0000277254.12230.7D

Glass, E.N. \& Kent, M. (2007) Neurologic System Emergencies. In A. Battaglia, Small Animal Emergency And Critical Care For Veterinary Technicians. Saunders, (2a ed.)

Huang, L., Wu, Z. B., Zhuge, Q., Zheng, W., Shao, B., Wang, B., Sun, F., \& Jin, K. (2014). Glial scar formation occurs in the human brain after ischemic stroke. International journal of medical sciences, 11(4), 344-348. https://doi.org/10.7150/ijms.8140

Huang, J. Y., Wang, Y. X., Gu, W. L., Fu, S. L., Li, Y., Huang, L. D., Zhao, Z., Hang, Q., Zhu, H. Q., \& Lu, P. H. (2012). Expression and function of myelinassociated proteins and their common receptor $\mathrm{NgR}$ on oligodendrocyte progenitor cells. Brain research, 1437, 1-15. https://doi.org/10.1016/j.brainres.2011.12.008

Lee, B. B., Cripps, R. A., Fitzharris, M., \& Wing, P. C. (2014). The global map for traumatic spinal cord injury epidemiology: update 2011, global incidence rate. Spinal cord, 52(2), 110-116. https://doi.org/10.1038/sc.2012.158

Li, Y., He, X., Kawaguchi, R., Zhang, Y., Wang, Q., Monavarfeshani, A., Yang, Z., Chen, B., Shi, Z., Meng, H., Zhou, S., Zhu, J., Jacobi, A., Swarup, V., Popovich, P. G., Geschwind, D. H., \& He, Z. (2020). Microglia-organized scar-free spinal cord repair in neonatal mice. Nature, 587(7835), 613-618. https://doi.org/10.1038/s41586-020-2795-6

Meyer, F.; Vialle, L.R.; Vialle, E.N.; Bleggi-Torres, L.F.; Rasera, E.; Leonel, I.(2013) Alterações vesicais na lesão medular experimental em ratos. ActaCirurgicaBrasileira, 18(3), 112-119.

National Spinal Cord Injury Statistical Center, N.S.C.I.S. Annual report for the spinal cord injury model system.

Rolls, A., Shechter, R., \& Schwartz, M. (2009). The bright side of the glial scar in CNS repair. Nature reviews. Neuroscience, 10(3), 235-241. https://doi.org/10.1038/nrn2591

Šedý, J., Zicha, J., Kunes, J., Jendelová, P., \& Syková, E. (2009). Rapid but not slow spinal cord compression elicits neurogenic pulmonary edema in the rat. Physiological research, 58(2), 269-277. https://doi.org/10.33549/physiolres.931508

Sofroniew M. V. (2005). Reactive astrocytes in neural repair and protection. The Neuroscientist : a review journal bringing neurobiology, neurology and psychiatry, 11(5), 400-407. https://doi.org/10.1177/1073858405278321

Sun, X., Kong, Q., Sun, K., Huan, L., Xu, X., Sun, J., \& Shi, J. (2020). Expression of Nogo-A in dorsal root ganglion in rats with cauda equina injury. Biochemical and biophysical research communications, 527(1), 131-137. https://doi.org/10.1016/j.bbrc.2020.04.094

Tang B. L. (2020). Nogo-A and the regulation of neurotransmitter receptors. Neural regeneration research, 15(11), 2037-2038. https://doi.org/10.4103/16735374.282250

Wang, J. W., Yang, J. F., Ma, Y., Hua, Z., Guo, Y., Gu, X. L., \& Zhang, Y. F. (2015). Nogo-A expression dynamically varies after spinal cord injury. Neural regeneration research, 10(2), 225-229. https://doi.org/10.4103/1673-5374.152375 
Research, Society and Development, v. 10, n. 6, e25410615688, 2021

(CC BY 4.0) | ISSN 2525-3409 | DOI: http://dx.doi.org/10.33448/rsd-v10i6.15688

Yang, T., Dai, Y., Chen, G., \& Cui, S. (2020). Corrigendum: Dissecting the Dual Role of the Glial Scar and Scar-Forming Astrocytes in Spinal Cord Injury. Frontiers in cellular neuroscience, 14, 270. https://doi.org/10.3389/fncel.2020.00270

Zhang, L., Lei, Z., Guo, Z., Pei, Z., Chen, Y., Zhang, F., Cai, A., Mok, G., Lee, G., Swaminathan, V., Wang, F., Bai, Y., \& Chen, G. (2020). Development of Neuroregenerative Gene Therapy to Reverse Glial Scar Tissue Back to Neuron-Enriched Tissue. Frontiers in cellular neuroscience, 14, 594170. https://doi.org/10.3389/fncel.2020.594170 